\title{
Targeted genome editing in acute lymphoblastic leukemia: a review
}

\author{
Adrián Montaño ${ }^{1 \dagger}$, Maribel Forero-Castro ${ }^{2 \dagger}$, Jesús-María Hernández-Rivas ${ }^{1,34^{*}}$, Ignacio García-Tuñón ${ }^{1}$ \\ and Rocío Benito'
}

\begin{abstract}
Background: Genome editing technologies offers new opportunities for tackling diseases such as acute lymphoblastic leukemia (ALL) that have been beyond the reach of previous therapies.

Results: We show how the recent availability of genome-editing tools such as CRISPR-Cas9 are an important means of advancing functional studies of ALL through the incorporation, elimination and modification of somatic mutations and fusion genes in cell lines and mouse models. These tools not only broaden the understanding of the involvement of various genetic alterations in the pathogenesis of the disease but also identify new therapeutic targets for future clinical trials.

Conclusions: New approaches including CRISPR-Cas9 are crucial for functional studies of genetic aberrations driving cancer progression, and that may be responsible for treatment resistance and relapses. By using this approach, diseases can be more faithfully reproduced and new therapeutic targets and approaches found.
\end{abstract}

Keywords: Acute lymphoblastic leukemia, CRISPR-Cas9, Genome editing

\section{Background}

Acute lymphoblastic leukemia (ALL) is a malignant disorder originating from hematopoietic B- or T-cell precursors, characterized by marked heterogeneity at the molecular and clinical levels. Although a genetic event is known to occur in the majority of cases, and may be associated with outcome prediction, around $25-30 \%$ of pediatric and $50 \%$ of adult ALL patients have no defined genetic hallmarks of biological or clinical significance [1].

The development of new techniques of genetic editing such as TALENs or CRISPR-Cas9 has made it possible to produce powerful animal genetic models that recapitulate the cooperating oncogenic lesions affecting genes with an established role in the proliferation and establishment of the leukemic clone [2]. In ALL, some approaches have been oriented towards analyzing the targeting of transcriptional factors such as $P A X 5$, which are involved

\footnotetext{
* Correspondence: jmhr@usal.es

${ }^{\dagger}$ Adrián Montaño and Maribel Forero-Castro contributed equally to this work. ${ }^{1}$ IBSAL, IBMCC, University of Salamanca-CSIC, Cancer Research Center, Salamanca, Spain

${ }^{3}$ Department of Medicine, University of Salamanca, Spain, Department of Hematology, University Hospital of Salamanca, Salamanca, Spain Full list of author information is available at the end of the article
}

in the pathogenesis of B-ALL, and TAL1 and LMO2, which are highly deregulated in T-ALL [3-5]. Targeting gene fusion expression has also been addressed through genome editing systems, as with $M L L$ and $A F 4$, whose fusion is associated with poor prognosis and which mainly affects B-ALL infants [6]. Other genes have been modified to gain a better understanding of the mechanism of action of several drugs, for example, $B T K$, target of ibrutinib, $X P O 1$, the target of KPT-8602, and CB1 and CB2, the targets of dronabinol [7, 8]. However, genome editing techniques have gone a step further and they have been used with therapeutic and clinical approaches. Their use has facilitated the design of new therapies such as chimeric antigen receptors (CARs) and have allowed the study of genes involved in the evolution of pathogenesis $[9,10]$.

\section{Targeted genome editing in ALL}

The development of next generation sequencing (NGS) techniques provided enormous amount of data to interpret, which generated the need to translate those data into functionally and clinically relevant knowledge that enable investigators to determinate how genotype influences phenotype. In the past decade, the integration of

(c) The Author(s). 2018 Open Access This article is distributed under the terms of the Creative Commons Attribution 4.0 International License (http://creativecommons.org/licenses/by/4.0/), which permits unrestricted use, distribution, and 
genome editing systems enables investigators to directly manipulate virtually any gene in a diverse range of cell types and organisms [11].

Genome editing system is based in the use of engineered nucleases composed of sequence-specific DNA-binding domains fused to a non-specific DNA cleavage module $[12,13]$. These chimeric nucleases inducing DNA doublestrand-breaks (DSBs) that stimulate the cellular DNA mechanisms, including error-prone non-homologous end joining (NHEJ) and homologous recombination (HR) [14]. Several approaches have been used in the last years as genome editing technologies (Fig. 1). The combination of simplicity and flexibility has hurtled zinc-finger nucleases (ZFNs), transcription activator-like effector nucleases (TALENs) and short palindromic repeats interspersed with regular intervals (CRISPR) to the forefront of genetic engineering (Fig. 2) [11].

ZFNs and TALENs were first used to generate knock-out rats in 2009 and 2011, respectively [15, 16]. TALENs system was first used in human cells in the same year [17]. CRISPR-Cas9 system, discovered as part of the prokaryotic adaptive immune system at the end of 1980s [18], was introduced some years later. This was proposed as a genetic modification system in 2005 [19] but was not tested until 2012 [20].

CRISPR-Cas9 is presented as a faster, cheaper, simpler system with the potential for multiplex genome editing [21]. The method is based on generating a directed cut in the double strand of DNA by the Cas9 nuclease. This is driven by a single 20-nucleotide RNA strand, which marks the exact breakage point. After DNA cutting, the DNA repair machinery of the host cell leads to repair errors and thereby promote a modification of the original sequence by a mutation such as an insertion, deletion or inversion, among others [22]. Based on CRISPR-Cas9 system, CRISPR interference (CRISPRi) and CRISPR activation (CRISPRa) emerged. CRISPRi uses a catalytically inactive version of Cas9 (dCas9) lacking endonucleolytic activity in combination with an sgRNA designed with a 20-bp complementary region to any gene of interest to silence a target gene [23]. While CRISPRa uses fusions of dCas9 to activator domains to activate gene expression [21].

Genome editing strategies have been used in several organisms, including Drosophila [24], Caenorhabditis elegans [25], zebrafish [26], mouse [27], rat [28], plants and humans [21] and has allowed a large number of functional studies to be carried out, based on the generation of animal and plant models. The use of genetically modified cell lines and animal models to understand the functions of genes and their pathogenesis in diseases conditioned by molecular genetics could be of help and provide insights to better understand cancer. The method used until now to generate these animal models, especially mice, is tedious and time-consuming, but CRISPR-Cas9 makes the procedure easier and more efficient [29].

Genome editing technologies, such as CRISPR-Cas9, have already been applied to the study of many diseases, including hematological diseases [30]. As exemplified by some

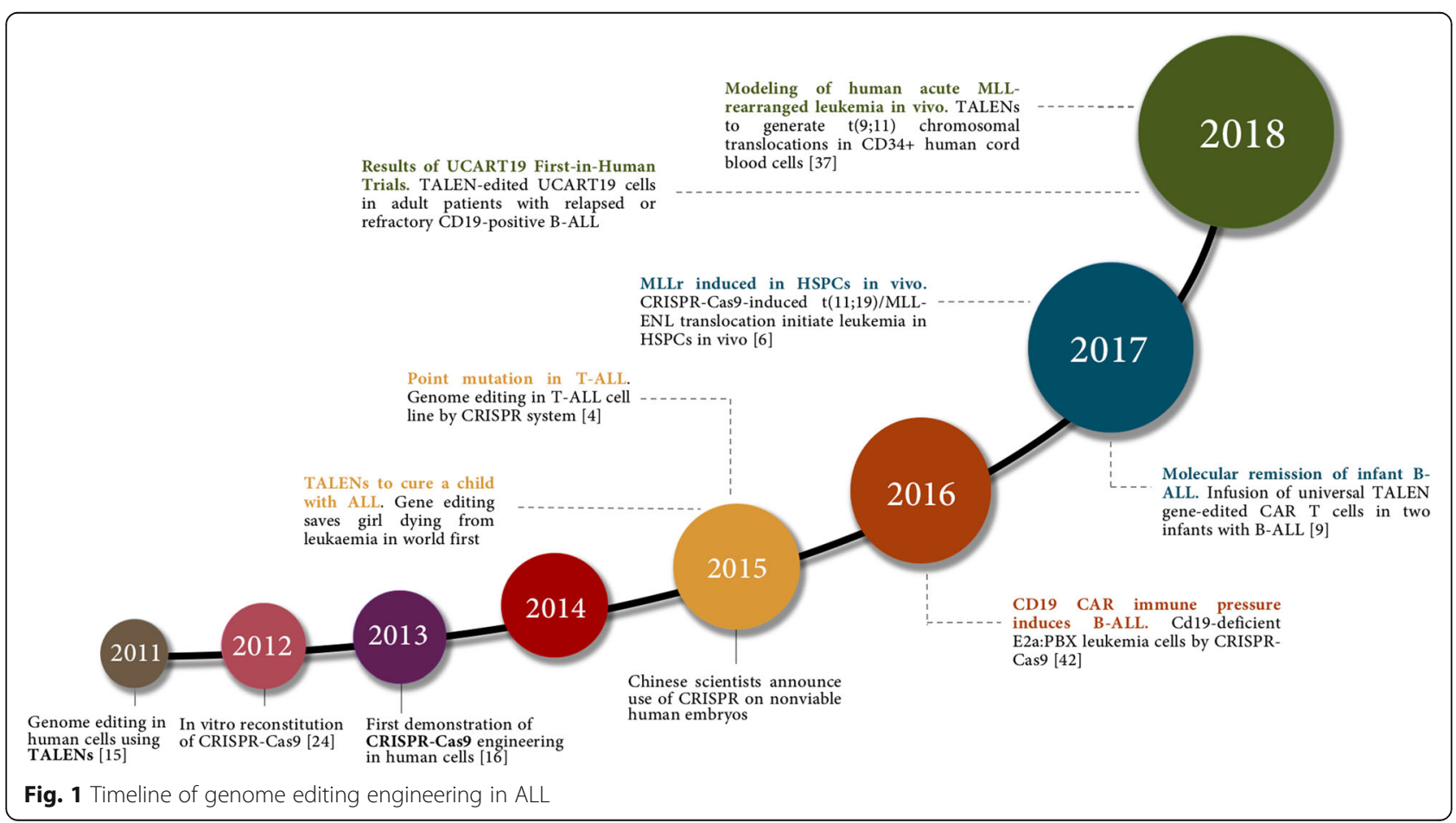




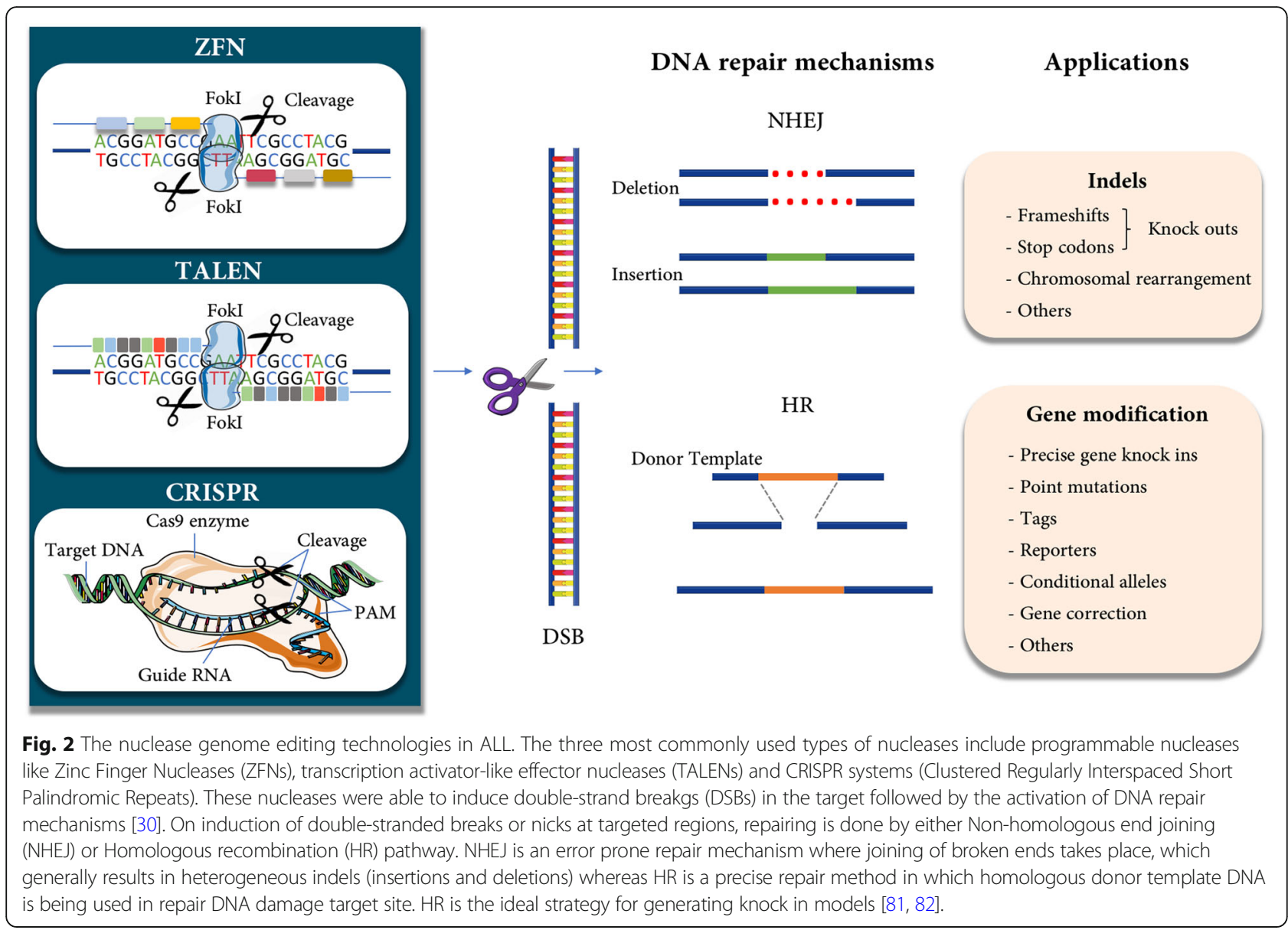

very recent studies in Fanconi anemia (FA), a genetic DNA repair-deficient human disorder that results from mutations in FA genes [31] or the study of BCR-ABL oncogene in chronic myeloid leukemia [32]. Specifically, most of the genetic modification studies in ALL have been with CRISPR-Cas9, more than 20 articles since 2015. The vast majority had the purpose of knocking out genes, either by introducing mutations, insertions or deletions.

An overview of recent studies in genome editing in ALL is summarized in Table 1. Some of the most relevant studies included in the table are detailed below.

\section{Targeting transcriptional factors}

Deregulation of Transcription factors (TFs) is a common mechanism in the pathogenesis of human cancer, in particular in leukemia cells, genes encoding TFs are often amplified, deleted, rearranged via chromosomal translocation, or subjected to point mutations that result in a gain- or loss-of-function. Consequently, targeting of TFs can be highly effective in treating ALL. TFs such as PAX5 and IKZF1 were altered in nearly $80 \%$ of patients with B-ALL [33, 34]. These alterations affected glucose metabolism and energy supply, whereby the transcription factors act as metabolic repressors by limiting the amount of ATP available. A CRISPR-Cas9-based screen of PAX5 and IKZF1 transcriptional targets identified some target genes such as NR3C1, TXNIP and CB2 as central effectors of B-lymphoid restriction of glucose and energy supply and therefore new targets for treating B-ALL [3].

In human T-cell acute lymphoblastic leukemia (T-ALL) cells, a CRISPR-Cas9 editing tool was used to disrupt TAL1 (SCL) [4] or TRIB1 (TRB1) [35] genes to delineate their biological functions. TAL1 is one of the oncogenes most frequently deregulated in T-ALL [36]. This deregulation is produced by $\mathrm{t}(1 ; 14)(\mathrm{p} 34 ; \mathrm{q} 11)(1-2 \%)$ or SIL(STIL)-TAL1 deletions $(\operatorname{del}(1)(\mathrm{p} 32))(15-20 \%)$, although there is still a large group of patients in whom the gene is deregulated but not altered. Epigenetics must therefore play an important role in these patients [37]. CRISPR-Cas9 was used in a cell line to reproduce two known alterations in TAL1 (insertion and deletion) and it was observed how these alterations triggered their expression. Furthermore, a change in methylation acetylation of H3K27 was observed, 
Table 1 Applications of genome editing systems in ALL

\begin{tabular}{|c|c|c|c|c|c|c|}
\hline & Outcome & Target Gene & $\begin{array}{l}\text { SSN } \\
\text { Technique }\end{array}$ & $\begin{array}{l}\text { Modification } \\
\text { Type }\end{array}$ & Cell type & Reference \\
\hline \multirow[t]{6}{*}{$\begin{array}{l}\text { Targeting } \\
\text { Transcriptional factors }\end{array}$} & $\begin{array}{l}\text { Point mutation } \\
\text { (insertion/deletion) }\end{array}$ & TAL1 & CRISPR-Cas9 & $\mathrm{HR}$ & PEER (in vitro) & [4] \\
\hline & Repress expression & PAX5 & CRISPR-a & NA & \multirow{4}{*}{$\begin{array}{l}\text { Patient-derived pre-B ALL } \\
\text { cells (in vitro) }\end{array}$} & \multirow[t]{4}{*}{ [3] } \\
\hline & \multirow[t]{3}{*}{ Knock out } & $N R 3 C 1$ & \multirow[t]{3}{*}{ CRISPR-Cas9 } & \multirow[t]{3}{*}{ NHEJ } & & \\
\hline & & TXNIP & & & & \\
\hline & & $C B 2$ & & & & \\
\hline & Knock out & LMO2 & CRISPR-Cas9 & NHEJ & PF-382 (in vitro) & [5] \\
\hline \multirow{7}{*}{$\begin{array}{l}\text { Targeting gene } \\
\text { fusion expression }\end{array}$} & \multirow{2}{*}{$\begin{array}{l}\text { Chromosomal } \\
\text { rearrangement }\end{array}$} & MLL/AF4 & \multirow[t]{2}{*}{ TALEN } & \multirow[t]{2}{*}{ NHEJ } & \multirow[t]{2}{*}{ K562, HSPCS (in vitro) } & \multirow[t]{2}{*}{ [42] } \\
\hline & & MLL/AF9 & & & & \\
\hline & Knock in & MLL/AF4 AF4/MLL & CRISPR-Cas9 & $H R$ & HEK293 (in vitro) & [46] \\
\hline & $\begin{array}{l}\text { Chromosomal } \\
\text { rearrangement }\end{array}$ & MLL/ENL & CRISPR-Cas9 & NHEJ & $\begin{array}{l}\text { HSPCS (in vitro / in vivo, } \\
\text { xenograft) }\end{array}$ & [6] \\
\hline & \multirow{2}{*}{$\begin{array}{l}\text { Chromosomal } \\
\text { rearrangement }\end{array}$} & MLL/AF9 & \multirow[t]{2}{*}{ TALEN } & \multirow[t]{2}{*}{ NHEJ } & \multirow{2}{*}{$\begin{array}{l}\text { CD34+ human cord blood } \\
\text { (in vivo, xenograft) }\end{array}$} & \multirow[t]{2}{*}{ [43] } \\
\hline & & AF9/MLL & & & & \\
\hline & Knock in & ETV6/RUNX1 & CRISPR-Cas9 & $\mathrm{HR}$ & MIFF3 hIPSCs (in vitro) & [40] \\
\hline \multirow{6}{*}{$\begin{array}{l}\text { Drug targts discovery } \\
\text { and therapy }\end{array}$} & \multirow[t]{2}{*}{ Knock out } & $C B 1$ & \multirow[t]{2}{*}{ CRISPR-Cas9 } & \multirow[t]{2}{*}{ NHEJ } & \multirow[t]{2}{*}{ Jurkat (in vitro) } & \multirow[t]{2}{*}{ [7] } \\
\hline & & $C B 2$ & & & & \\
\hline & \multirow[t]{2}{*}{ Knock out } & BTK & \multirow[t]{2}{*}{ CRISPR-Cas9 } & \multirow[t]{2}{*}{ NHEJ } & RCH-ACV (in vitro / in vivo, & [8] \\
\hline & & $B L K$ & & & xenograft) & \\
\hline & Knock in & XPO1 & CRISPR-Cas9 & $\mathrm{HR}$ & $\begin{array}{l}\mathrm{HL}-60 \text {, Jurkat, K-562, and MOLT-4 } \\
\text { (in vitro / in vivo, xenograft) }\end{array}$ & {$[57]$} \\
\hline & Knock out & $A B C B 1$ & CRISPR-Cas9 & NHEJ & HALO1 (in vitro) & [59] \\
\hline Modification of CARs & Knock out & CD19 & CRISPR-Cas9 & NHEJ & $\begin{array}{l}\text { NALM6, } 697 \text { (in vitro / in vivo, } \\
\text { xenograft) }\end{array}$ & [65] \\
\hline & Knock out & $C D 19$ & CRISPR-Cas9 & NHEJ & Murine leukemia cell lines E2a:PBX & [83] \\
\hline & & PAX5 & & & & \\
\hline & & EBF1 & & & & \\
\hline & Knock out & TRAC & CRISPR-Cas9 & $H R$ & NALM6 (in vitro / in vivo, xenograft) & [63] \\
\hline & Knock in & $C D 19$ & & & & \\
\hline & Knock out & CD52 & TALEN & NHEJ & Two infants (in vivo) & [9] \\
\hline & & $T C R a b$ & & & & \\
\hline & Knock out & $T C R b$ & CRISPR-Cas9 & NHEJ & PBMC (in vitro) & [84] \\
\hline & Knock out & $C D 7$ & CRISPR-Cas9 & NHEJ & T cell lines (in vitro / in & [85] \\
\hline & & TRAC & & & $\mathrm{VI}$ & \\
\hline Evolution of & Knock out & CASD1 & CRISPR-Cas9 & NHEJ & HAP1 (in vitro) & [70] \\
\hline & Knock out & RIP1 & CRISPR-Cas9 & NHEJ & $\begin{array}{l}\text { Patient-derived ALL cells } \\
\text { (in vitro / in vivo, xenograft) }\end{array}$ & [75] \\
\hline & Knock out & CXCR4 & CRISPR-Cas9 & NHEJ & $\begin{array}{l}\text { NALM6 (in vitro / in vivo, } \\
\text { xenograft) }\end{array}$ & [10] \\
\hline Others & Knock out & FLT3 & TALEN & NHEJ & K562 (in vitro) & [86] \\
\hline & Knock out screen & NA & CRISPR-Cas9 & NHEJ & NALM6 (in vitro) & [87] \\
\hline & Knock out screen & NA & CRISPR-Cas9 & NHEJ & MV4,11 (in vitro) & [88] \\
\hline & Knock out & NUDT15 & CRISPR-Cas9 & NHEJ & Mouse (in vivo) & [89] \\
\hline & Knock out & $D C K$ & CRISPR-Cas9 & NHEJ & KOPN41 (in vitro) & [90] \\
\hline & Knock out & PTCH1 & CRISPR-Cas9 & NHEJ & Zebrafish embryos (in vivo, xenograft) & [91] \\
\hline
\end{tabular}

This table shows the main genetic editing studies carried out in ALL, classified according to the target. The different columns indicate: the outcome of edition, the target of edition (highlighted in bold), the technique used, the type of modification, the cell type and the reference 
suggesting a causal relationship between mutagenesis, epigenetic modulation and expression of TAL1 [4].

LMO2 is another gene deregulated in T-ALL. It is a potent oncogene that is essential for the formation of a large transcriptional complex in which genes such as TAL1, LDB1, GATA1, GATA2, GATA3, RUNX1, ETS1, and $M Y B$ intervene. Furthermore, its overexpression has been associated with the development of T-ALL. However, the reasons why this gene is overexpressed remain unclear, because few mutations have been described. Mutations targeted to the non-coding region of LMO2 were introduced in a T-ALL cell line by CRISPR-Cas9 and proved to be a possible cause of the deregulation of LMO2 expression [5].

\section{Targeting gene fusion expression in ALL with chromosomal rearrangements}

As indicated above, chromosomal translocations are very frequent in ALL and can be used to stratify the risk of ALL patients. It is well known that $M L L$ rearrangements occur in a small percentage of B-ALL patients, where they are associated with very poor prognosis. Several studies have proposed that $M L L$ rearrangements are an initiating event in leukemic transformation, unlike ETV6-RUNX1 and BCR-ABL translocations, in which second events are necessary to initiate leukemia [33, 38, 39]. This was demonstrated by Enver T's group, who used a homologous recombination knock-in approach by CRISPR-Cas9 to introduce the cDNA encoding of RUNX1 exons 2-8 into the native ETV6 locus of hIPSC. ETV6-RUNX1 expression induced a partial block of the maturation of B lymphocytes, at which time the second events required for leukemia development occurs [40].

Matthew Porteus's group wanted to test the oncogenic potential as initiator event of the $M L L$ translocations, and for this purpose, they generated the MLL-AF4 and MLL-AF9 translocations by genetic modification in primary hematopoietic stem and progenitor cells (HSPCs). This strategy was based on previous studies that demonstrated that the double-stranded DNA breakage at specific positions of two chromosomes could lead to translocation [41]. They used TALENs to generate cuts directed at specific positions of MLL-AF4 and AF9, based on the breakage points described in patients. In vitro, the cells that acquired the translocation showed a proliferative advantage over the others but were not able to transform completely because they eventually disappeared from the culture [42].

Shortly after, Heckl D.'s group showed strong evidence for the formation of true $t(11 ; 19) / M L L-A F 9$ translocations in vitro and in vivo by CRISPR-Cas9. No full transformation was observed in liquid cultures or methylcellulosebased in vitro assays using CD34+ HSPC, while in vivo assays demonstrated that endogenous $t(11 ; 19)$ can initiate a monocytic leukemia-like phenotype. This study is in line with the Matthew Porteus's study, which emphasizes the importance of environmental cues for the oncogenic transformation in $M L L r$ leukemias [6].

More recently, Stanford's group managed to generate $t$ $(9 ; 11)$ chromosomal translocations encoding MLL-AF9 and reciprocal AF9-MLL fusion products in CD34+ human cord blood cells by TALENs. Transplantation of these cells into immune-compromised mice induced myeloid leukemias with absence of secondary lesions studied by targeted exome sequencing and RNAseq [43].

The prevailing theory is that $M L L$ rearrangements occur in the uterus due to exposure to certain chemicals during pregnancy that cause errors in DNA repair, as has been demonstrated in vitro and in vivo $[44,45]$. The group of Pablo Menéndez examined how it affected the expression of the fusion protein in repairing DNA damage. To this end, MLL-AF4 protein and its reciprocal, AF4-MLL were induced in the AAVS1 locus of the HEK293 cell line by CRISPR-Cas9. They subsequently induced DNA damage by exposing the cells to etoposide and ionizing radiation (IR), with no differences in repair between WT cells and those expressing proteins. Thus, they demonstrated that the expression of the fusion proteins caused by $M L L$ rearrangements, did not influence susceptibility to DNA damage or repair mechanisms [46].

\section{Drug targets discovery and therapy}

The targets against which a drug acts must be identified and combined with the data provided by the NGS. This may sometimes identify patients with mutations in genes associated with some type of resistance. It can also help to generate other new drugs, when there is prior knowledge of the altered pathway we wish to attack. For example, ibrutinib has recently been proposed for the treatment of pre-BCR and TCF3-r-positive cases. Ibrutinib is an inhibitor kinase targeted to those ALL subtypes with affected BCR signaling. In order to understand the mechanism of action of ibrutinib in this ALL subtype, Bruton tyrosine kinase (BTK) KO, B lymphocyte kinase $(B L K) \mathrm{KO}$ and $B T K / B L K \mathrm{KO}$ cells have been generated by CRISPR-Cas9 [8].

The importance of BTK in the pathogenesis of chronic lymphocytic leukemia, diffuse large B-cell lymphoma, and other mature B-cell malignancies is well established [47-49], while there is less information about the role of $B T K$ in ALL. Early studies reported unaltered levels of $B T K$ in childhood ALL cells, whereas frequent BTK deficiency due to aberrant splicing was reported later $[50,51] . B L K$ and $B T K$ were the only kinase genes overexpressed in this subtype of ALL, as revealed by arrays [52]. Only the elimination of the expression of both 
kinases managed to reduce the proliferation in a similar way to ibrutinib. However, these should not be the only targets of ibrutinib since the decrease in proliferation was still greater when the drug was used. To confirm that $B T K$ and $B L K$ were actually drug targets, ibrutinib was tested in cell lines generated with $\mathrm{KO}$ genes. This indicated that ibrutinib requires the presence of both kinases for maximum effectiveness [8].

In a subsequent study, Thomas Vercruysse and coworkers focused on exportin 1 (XPO1). XPO1 plays an important role in the transport through the nucleus of cycle regulatory proteins and tumor suppressor proteins, among others. The overexpression of this gene is associated with several types of cancer, and with poor patient outcome $[53,54]$. XPO1 inhibitors act by binding to the reactive cysteine residue located at position 528, preventing the export of charged proteins to the cytoplasm $[55,56]$. To verify that the drug binds specifically to act against XPO1, a point mutation was inserted at residue 528 by CRISPR-Cas9. When this occurred, the drug was not able to act, and the cells became resistant. Therefore, this study demonstrated that the drug is highly specific to XPO1 and is potent against ALL [57].

More recently, Dronabinol (Tetrahydrocannabinol, THC), a US Food and Drug Administration-approved cannabinoid receptor $(\mathrm{CNB})$ agonist for the treatment of chemotherapy-induced nausea and vomiting, was found to induce apoptosis in acute leukaemia cells, as evidenced by the abrogation of pro-apoptotic effects of CRISPR-mediated knockout of $C B 1$ or $C B 2$ following THC treatment $[7,58]$.

Furthermore, new drugs are being proposed as an alternative to current therapy. An example is Carfilzomib (CFZ), as a substitute of proteasome inhibitor Bortezomib (BTZ), who demonstrated favorable clinical outcomes for refractory childhood ALL. CFZ showed significantly higher activity than BTZ in vitro, except for the P-glycoprotein-positive $t(17 ; 19)$ ALL cell lines. Takahashi et al. generated a knock-out of $A B C B 1$, who codes for P-glycoprotein, by genome editing with a CRISPR-Cas9 system and sensitized P-glycoprotein-positive t $(17 ; 19)$ ALL cell line to CFZ [59].

\section{Modification of CAR}

Chemotherapy and/or radiotherapy have been standard treatments for ALL to date. However, immunological therapies have gained importance. These work by harnessing the immune system of patients to fight the disease. One example is chimeric antigen receptors (CARs), which are proteins genetically engineered to allow $\mathrm{T}$ cells to recognize a specific antigen in tumor cells. It had already been proposed as a standard therapy for ALL patients in 2013 by Rosenberg. In this case, the CARs were directed against CD19, an antigen of B cells
[60]. Its efficacy had already been demonstrated in cases of refractory or relapsed ALL $[61,62]$.

CRISPR-Cas9 may be key to carry out this genetic modification. This was demonstrated by Michel Sadelain's group. The strategy followed was the combination of knock-out and knock-in. On the one hand, they interrupted the TRAC locus, and on the other, they added a CAR directed to CD19, inserting it in the AAVS1 locus. hey compared responses to CD19 antigens from these cells with those from others in which CAR had been randomly integrated. In this way, they were able to demonstrate that targeted CAR integration under the control of endogenous regulatory elements is much more effective, reduces tonic signaling, avoids the differentiation and accelerated depletion of $\mathrm{T}$ cells, and increases the therapeutic potential of these cells [63].

Paul Veys's group demonstrated the use of TALENmodified $\mathrm{T}$ lymphocytes in two infants with refractory B-ALL. They generated universal T-cells against CD19 (CAR19), targeting the TALENs against the T-cell receptor (TCR) and simultaneously transfecting with non-human leukocyte donor cell antigens. As treated cells, they disrupted the CD52 gene, the target of the drug alemtuzumab, by TALEN, and also disrupted the expression of the $\alpha \beta$ T cell surface receptor (TCR $\alpha \beta$ ). This minimized the risk of graft-versus-host disease (GVHD). The newborns were treated with lymphoplasty, chemotherapy and anti-CD52 serotherapy before infusion of CAR19. The results were very positive, yielding remissions within 28 days before allogeneic stem cell transplantation [9].

Despite the good results with CAR19 therapy, $10-20 \%$ of treated patients suffer relapses due to partial loss of the CD19 epitope [61, 64]. Andrei Thomas-Tikhonenko and his group have provided evidence that epitope loss is closely linked to alterations in exon 2 of CD19, detected in some samples from patients with relapses. These alterations include frameshift-type mutations and the total loss of the exon, resulting from an alternative splicing event that encodes a deficient isoform of exon 2. To assess the relevance of the detected isoforms, they eliminated CD19 expression by CRISPR-Cas9 from ALL cell lines, and then reconstituted them with different isoforms. They observed that the depleted isoform of exon 2 was located mostly in the cytosol, which could explain its mechanism of escape in front of CAR19. Thus, these deleterious mutations and the selection of isoforms resulting from alternative splicing could be the cause of this mechanism of resistance [65].

\section{Evolution of pathogenesis}

Although there have been great advances in the treatment and cure of ALL, there is still a large group of 
patients who experience relapses, persistent minimal residual disease, and drug resistance, and who ultimately have a poor prognosis [66, 67]. Efforts have therefore focused on trying to understand why these resistances occur, to counteract them, and to look for new, more personalized drugs that avoid resistance.

In ALL, survival and drug resistance of lymphoblasts critically depend on 9-O-acetylation of sialic acids (Sias) $[68,69]$. Baumann AM et al., generated a CASD1 knock-out cells by CRISPR-Cas9-mediated genome editing and demonstrated that CASD1 is essential for 9-O-acetylation [70].

Second mitochondrial-derived caspase-activators (SMACs) act by inhibiting inhibitors of apoptosis proteins (IAPs). One of the possible causes of resistance is revealed by the action of these proteins, which act to counteract the effects of drugs. These are also overexpressed in many types of cancer [71, 72]. The main mechanism of action of IAPs is the inhibition of apoptosis through proteins such as caspases [73] or receptor interaction of protein kinase 1 (RIP1), a potent activator of death [74]. In this study, they set out to demonstrate that SMAC acted by reactivating apoptosis of these cells, mediated by RIP1. They used CRISPR-Cas9 system to knock out this gene in vivo in xenograft models, and thereby eliminate its expression. The results showed that RIP1 was necessary for the induction of cell death by SMAC [75].

CXCR4 encodes a membrane receptor whose function is to attract and confine the stromal cells of the bone marrow stromal cells (BMSCs). This interaction with BMSCs gives $\mathrm{B}$ cells a degree of protection, associated with increased survival, resistance to treatment, relapse and worse prognosis $[76,77]$. CXCR4 is highly expressed in B-ALL cells and has also been correlated with poor patient outcome [78]. Inhibitors of CXCR4 have already been examined in the preclinical setting, in vitro and in vivo $[79,80]$ and may be $C X C R 4$ antagonists or agonists. To test whether the efficacy of these compounds was due to the inhibition of CXCR4 and not to their own activity as agonists, they generated a B-ALL cell line with CXCR4 knock-out by CRISPR-Cas9. They demonstrated that the agonistic activity of CXCR4 antagonists did not affect antitumor activity. In addition, in vivo CXCR4 knock-out models reduced the burden of leukemia and disease progression. In this way, the importance of CXCR4 in the pathogenesis of B-ALL and in its use as a therapeutic target to fight drug resistance is demonstrated [10].

\section{Conclusions, challenges and future directions}

Genome editing technologies have already demonstrated its potential to study molecular biology and pathogenesis of the genetic aberrations in ALL, in vitro and in vivo.
From a future perspective, the development of the genomic editing tools could also help to the generation of murine models of leukemias that resemble the human disease. In this sense, multigenic nature of the disease entails great difficulties. In the case of ALL, murine models based on a single alteration have failed, at least in part, to fully develop the disease. Combining several of the gene alterations found in patients in a murine model, we could approach to the real pathological conditions, giving rise to a more efficient model for the investigation of this type of tumors. Until recently, to generate an animal model with several genetic alterations was a long and expensive process, however, tools such us, CRISPR-Cas9, will allow introducing multiple mutations in a single step. Thus, it will be possible to generate, in short periods of time, more complex animal models that allow us to simulate more faithfully the conditions that occur in patients, providing the appropriate platform to study and to develop new therapeutic strategies.

Furthermore, in the clinic, genome editing systems could facilitate the rapid screening of new drugs and will promote the development of personalized medicine, connecting genomics, disease phenotypes and therapeutic goals. The use of these technologies will broaden our understanding of the mechanism of action of these novel drugs and enable the identification of novel mechanisms of acquired resistance to pathway target therapeutics. However, translating genome editing technologies to the clinical setting requires two main concerns to be addressed: the safety and efficacy of treatments. The off-target effect remains one of the major obstacles of this technology. Researches will need to improve our genetic tools in order to eliminate any off-target effects and to improve the gene edition efficiency in the future. Despite this, genome editing offers new opportunities for tackling diseases such as ALL that have been beyond the reach of previous therapies.

\footnotetext{
Abbreviations

ALL: Acute lymphoblastic leukemia; AML: Acute myeloid leukemia; BCR: B-cell receptor signaling; BMSCs: Bone marrow stromal cells; CARs: Chimeric antigen receptors; CRISPR: Short palindromic repeats interspersed with regular intervals; DSBs: Double-strand breaks; HiPSC: Human induced pluripotent stem cell; HR: Homologous recombination; HSPCs: Hematopoietic stem and progenitor cells; IAPs: Inhibitors of apoptosis proteins; IR: Ionizing radiation; MMEJ: Micro-homology-mediated end-joining; NGS: Next generation sequencing; NHEJ: Non-homologous end-joining; PBMC: Peripheral blood mononuclear cell; Sias: Sialic acids; SMACs: Second mitochondrial-derived caspase-activators; TALENs: Transcription-activating type nucleases; TCR: T-cell receptor; THC: Tetrahydrocannabinol; ZFNs: Zinc finger nucleases
}

\section{Acknowledgements}

Part of this work was support by a grant to AM from the Junta Provincial de Salamanca of the Asociación Española Contra el Cáncer (AECC), and a grant to MFC from the Universidad Pedagógica y Tecnológica de Colombia - 
Vicerrectoría de Investigación y Extensión (Grupo de Investigación en Ciencias Biomédicas UPTC - GICBUPTC, Escuela de Ciencias Biológicas).

\section{Funding}

This work was financially supported in part by a grant from the Consejería de Educación, Junta de Castilla y León, Fondos FEDER (SA085U16), Proyectos de Investigación del SACYL, Spain (BIO/SA10/14), a grant to AM from the Junta Provincial de Salamanca of the Asociación Española Contra el Cáncer (AECC), and a grant to MFC from the Universidad Pedagógica y Tecnológica de Colombia - Vicerrectoría de Investigación y Extensión (Grupo de Investigación en Ciencias Biomédicas UPTC - GICBUPTC, Escuela de Ciencias Biológicas).

\section{Authors' contributions}

AMB and MFC wrote the manuscript. All authors contributed to editing and approval of the final manuscript.

\section{Ethics approval and consent to participate}

Not applicable.

\section{Consent for publication}

Not applicable.

\section{Competing interests}

The authors declare that they have no competing interests.

\section{Publisher's Note}

Springer Nature remains neutral with regard to jurisdictional claims in published maps and institutional affiliations.

\section{Author details}

${ }^{1}$ IBSAL, IBMCC, University of Salamanca-CSIC, Cancer Research Center, Salamanca, Spain. ${ }^{2}$ School of Biological Sciences (GICBUPTC Research group), Universidad Pedagógica y Tecnológica de Colombia, Boyacá, Colombia. ${ }^{3}$ Department of Medicine, University of Salamanca, Spain, Department of Hematology, University Hospital of Salamanca, Salamanca, Spain. ${ }^{4}$ IBMCC, CIC University of Salamanca-CSIC, University Hospital of Salamanca, Salamanca, Spain.

\section{Received: 28 February 2018 Accepted: 5 July 2018}

Published online: 17 July 2018

\section{References}

1. lacobucci I, Mullighan CG. Genetic basis of acute lymphoblastic leukemia. J Clin Oncol. 2017;35(9):975-83.

2. Nemudryi AA, Valetdinova KR, Medvedev SP, Zakian SM. TALEN and CRISPR/ Cas genome editing systems: tools of discovery. Acta Nat. 2014;6(3):19-40.

3. Chan LN, Chen Z, Braas D, Lee JW, Xiao G, Geng H, Cosgun KN, Hurtz C, Shojaee S, Cazzaniga V, et al. Metabolic gatekeeper function of B-lymphoid transcription factors. Nature. 2017;542(7642):479-83.

4. Navarro JM, Touzart A, Pradel LC, Loosveld M, Koubi M, Fenouil R, Le Noir S, Maqbool MA, Morgado E, Gregoire C, et al. Site- and allele-specific polycomb dysregulation in T-cell leukaemia. Nat Commun. 2015;6:6094

5. Rahman S, Magnussen M, Leon TE, Farah N, Li Z, Abraham BJ, Alapi KZ, Mitchell RJ, Naughton T, Fielding AK, et al. Activation of the LMO2 oncogene through a somatically acquired neomorphic promoter in T-cell acute lymphoblastic leukemia. Blood. 2017:129(24):3221-6.

6. Reimer J, Knoss S, Labuhn M, Charpentier EM, Gohring G, Schlegelberger B, Klusmann JH, Heckl D. CRISPR-Cas9-induced t(11:19)/MLL-ENL translocations initiate leukemia in human hematopoietic progenitor cells in vivo. Haematologica. 2017;102(9):1558-66.

7. Kampa-Schittenhelm KM, Salitzky O, Akmut F, Illing B, Kanz L, Salih HR, Schittenhelm MM. Dronabinol has preferential antileukemic activity in acute lymphoblastic and myeloid leukemia with lymphoid differentiation patterns. BMC Cancer. 2016;16:25.

8. Kim E, Hurtz C, Koehrer S, Wang Z, Balasubramanian S, Chang BY, Muschen M, Davis RE, Burger JA. Ibrutinib inhibits pre-BCR+ B-cell acute lymphoblastic leukemia progression by targeting BTK and BLK. Blood. 2017; 129(9):1155-65.
9. Qasim W, Zhan H, Samarasinghe S, Adams S, Amrolia P, Stafford S, Butler K, Rivat C. Wright G, Somana K, et al. Molecular remission of infant B-ALL after infusion of universal TALEN gene-edited CAR T cells. Sci Transl Med. 2017;9(374)

10. Randhawa S, Cho BS, Ghosh D, Sivina M, Koehrer S, Muschen M, Peled A, Davis RE, Konopleva M, Burger JA. Effects of pharmacological and genetic disruption of CXCR4 chemokine receptor function in B-cell acute lymphoblastic leukaemia. Br J Haematol. 2016;174(3):425-36.

11. Gaj T, Gersbach CA, Barbas CF 3rd. ZFN, TALEN, and CRISPR/Cas-based methods for genome engineering. Trends Biotechnol. 2013;31(7):397-405.

12. Urnov FD, Rebar EJ, Holmes MC, Zhang HS, Gregory PD. Genome editing with engineered zinc finger nucleases. Nat Rev Genet. 2010;11(9):636-46.

13. Carroll D. Genome engineering with zinc-finger nucleases. Genetics. 2011; 188(4):773-82

14. Wyman C, Kanaar R. DNA double-strand break repair: all's well that ends well. Annu Rev Genet. 2006:40:363-83.

15. Geurts AM, Cost GJ, Freyvert Y, Zeitler Z, Miller JC, Choi VM, Jenkins SS, Wood A, Cui $X$, Meng $X$, et al. Knockout rats produced using designed zinc finger nucleases. Science. 2009;325(5939):433.

16. Tesson L, Usal C, Menoret S, Leung E, Niles BJ, Remy S, Santiago Y, Vincent Al, Meng $X$, Zhang $L$, et al. Knockout rats generated by embryo microinjection of TALENs. Nat Biotechnol. 2011:29(8):695-6.

17. Miller JC, Tan S, Qiao G, Barlow KA, Wang J, Xia DF, Meng X, Paschon DE, Leung E, Hinkley SJ, et al. A TALE nuclease architecture for efficient genome editing. Nat Biotechnol. 2011;29(2):143-8.

18. Ishino $Y$, Shinagawa $H$, Makino $K$, Amemura M, Nakata A. Nucleotide sequence of the iap gene, responsible for alkaline phosphatase isozyme conversion in Escherichia coli, and identification of the gene product. $J$ Bacteriol. 1987:169(12):5429-33.

19. Mojica FJ, Diez-Villasenor C, Garcia-Martinez J, Soria E. Intervening sequences of regularly spaced prokaryotic repeats derive from foreign genetic elements. J Mol Evol. 2005;60(2):174-82.

20. Jinek M, Chylinski K, Fonfara I, Hauer M, Doudna JA, Charpentier E. A programmable dual-RNA-guided DNA endonuclease in adaptive bacterial immunity. Science. 2012;337(6096):816-21.

21. Mali P, Yang L, Esvelt KM, Aach J, Guell M, DiCarlo JE, Norville JE, Church GM. RNA-guided human genome engineering via Cas9. Science. 2013; 339(6121):823-6.

22. Cong L, Ran FA, Cox D, Lin S, Barretto R, Habib N, Hsu PD, Wu X, Jiang W, Marraffini LA, et al. Multiplex genome engineering using CRISPR/Cas systems. Science. 2013;339(6121):819-23.

23. Larson MH, Gilbert LA, Wang X, Lim WA, Weissman JS, Qi LS. CRISPR interference (CRISPRi) for sequence-specific control of gene expression. Nat Protoc. 2013:8(11):2180-96.

24. Yu Z, Ren M, Wang Z, Zhang B, Rong YS, Jiao R, Gao G. Highly efficient genome modifications mediated by CRISPR/Cas9 in Drosophila. Genetics. 2013;195(1):289-91.

25. Dickinson DJ, Ward JD, Reiner DJ, Goldstein B. Engineering the Caenorhabditis elegans genome using Cas9-triggered homologous recombination. Nat Methods. 2013:10(10):1028-34.

26. Chang N, Sun C, Gao L, Zhu D, Xu X, Zhu X, Xiong JW, Xi JJ. Genome editing with RNA-guided Cas9 nuclease in zebrafish embryos. Cell Res. 2013, 23(4):465-72

27. Wang $H$, Yang $H$, Shivalila CS, Dawlaty MM, Cheng AW, Zhang F, Jaenisch $R$. One-step generation of mice carrying mutations in multiple genes by CRISPR/Cas-mediated genome engineering. Cell. 2013;153(4):910-8.

28. Li D, Qiu Z, Shao Y, Chen Y, Guan Y, Liu M, Li Y, Gao N, Wang L, Lu X, et al. Heritable gene targeting in the mouse and rat using a CRISPR-Cas system. Nat Biotechnol. 2013;31(8):681-3.

29. Xiong X, Chen M, Lim WA, Zhao D, Qi LS. CRISPR/Cas9 for human genome engineering and disease research. Annu Rev Genomics Hum Genet. 2016; 17:131-54.

30. Osborn MJ, Webber BR, Knipping F, Lonetree CL, Tennis N, DeFeo AP, McElroy AN, Starker CG, Lee C, Merkel S, et al. Evaluation of TCR gene editing achieved by TALENs, CRISPR/Cas9, and megaTAL nucleases. Mol Ther. 2016;24(3):570-81.

31. Osborn MJ, Gabriel R, Webber BR, DeFeo AP, McElroy AN, Jarjour J, Starker CG, Wagner JE, Joung JK, Voytas DF, et al. Fanconi anemia gene editing by the CRISPR/Cas9 system. Hum Gene Ther. 2015:26(2):114-26.

32. Garcia-Tunon I, Hernandez-Sanchez M, Ordonez JL, Alonso-Perez V, AlamoQuijada M, Benito R, Guerrero C, Hernandez-Rivas JM, Sanchez-Martin M. The CRISPR/Cas9 system efficiently reverts the tumorigenic ability of BCR/ 
$A B L$ in vitro and in a xenograft model of chronic myeloid leukemia. Oncotarget. 2017;8(16):26027-40.

33. Mullighan CG, Goorha S, Radtke I, Miller CB, Coustan-Smith E, Dalton JD, Girtman K, Mathew S, Ma J, Pounds SB, et al. Genome-wide analysis of genetic alterations in acute lymphoblastic leukaemia. Nature. 2007; 446(7137):758-64.

34. Mullighan CG, Phillips LA, Su X, Ma J, Miller CB, Shurtleff SA, Downing JR. Genomic analysis of the clonal origins of relapsed acute lymphoblastic leukemia. Science. 2008;322(5906):1377-80

35. Miyajima C, Inoue Y, Hayashi H. Pseudokinase tribbles 1 (TRB1) negatively regulates tumor-suppressor activity of p53 through p53 deacetylation. Biol Pharm Bull. 2015;38(4):618-24.

36. Sanda T, Lawton LN, Barrasa MI, Fan ZP, Kohlhammer H, Gutierrez A, Ma W, Tatarek J, Ahn Y, Kelliher MA, et al. Core transcriptional regulatory circuit controlled by the TAL1 complex in human T cell acute lymphoblastic leukemia. Cancer Cell. 2012;22(2):209-21.

37. Ferrando AA, Herblot S, Palomero T, Hansen M, Hoang T, Fox EA, Look AT. Biallelic transcriptional activation of oncogenic transcription factors in T-cell acute lymphoblastic leukemia. Blood. 2004;103(5):1909-11.

38. Greaves MF, Wiemels J. Origins of chromosome translocations in childhood leukaemia. Nat Rev Cancer. 2003;3(9):639-49.

39. Greaves M. A causal mechanism for childhood acute lymphoblastic leukaemia. Nat Rev Cancer. 2018;

40. Boiers C, Richardson SE, Laycock E, Zriwil A, Turati VA, Brown J, Wray JP, Wang D, James C, Herrero J, et al. A human IPS model implicates embryonic B-myeloid fate restriction as developmental susceptibility to $B$ acute lymphoblastic leukemia-associated ETV6-RUNX1. Dev Cell. 2018;44(3): 362-77. e367

41. Weinstock DM, Brunet $E$, Jasin $M$. Induction of chromosomal translocations in mouse and human cells using site-specific endonucleases. J Natl Cancer Inst Monogr. 2008;2008(39):20-4.

42. Breese EH, Buechele C, Dawson C, Cleary ML, Porteus MH. Use of genome engineering to create patient specific MLL translocations in primary human hematopoietic stem and progenitor cells. PLoS One. 2015;10(9):e0136644

43. Schneidawind C, Jeong J, Schneidawind D, Kim IS, Duque-Afonso J, Wong SHK, Iwasaki M, Breese EH, Zehnder JL, Porteus M, et al. MLL leukemia induction by $\mathrm{t}(9 ; 11)$ chromosomal translocation in human hematopoietic stem cells using genome editing. Blood Adv. 2018;2(8):832-45.

44. Bueno C, Catalina P, Melen GJ, Montes R, Sanchez L, Ligero G, Garcia-Perez $J$, Menendez P. Etoposide induces MLL rearrangements and other chromosomal abnormalities in human embryonic stem cells. Carcinogenesis. 2009;30(9):1628-37.

45. Nanya M, Sato M, Tanimoto K, Tozuka M, Mizutani S, Takagi M. Dysregulation of the DNA damage response and KMT2A rearrangement in fetal liver hematopoietic cells. PLoS One. 2015;10(12):e0144540.

46. Castano J, Herrero AB, Bursen A, Gonzalez F, Marschalek R, Gutierrez NC, Menendez P. Expression of MLL-AF4 or AF4-MLL fusions does not impact the efficiency of DNA damage repair. Oncotarget. 2016;7(21):30440-52.

47. Herman SE, Gordon AL, Hertlein E, Ramanunni A, Zhang X, Jaglowski S, Flynn J, Jones J, Blum KA, Buggy JJ, et al. Bruton tyrosine kinase represents a promising therapeutic target for treatment of chronic lymphocytic leukemia and is effectively targeted by PCl-32765. Blood. 2011;117(23):6287-96.

48. Ponader S, Chen SS, Buggy JJ, Balakrishnan K, Gandhi V, Wierda WG, Keating MJ, O'Brien S, Chiorazzi N, Burger JA. The Bruton tyrosine kinase inhibitor PCI-32765 thwarts chronic lymphocytic leukemia cell survival and tissue homing in vitro and in vivo. Blood. 2012;119(5):1182-9.

49. Davis RE, Ngo VN, Lenz G, Tolar P, Young RM, Romesser PB, Kohlhammer H, Lamy L, Zhao H, Yang Y, et al. Chronic active B-cell-receptor signalling in diffuse large B-cell lymphoma. Nature. 2010;463(7277):88-92.

50. Goodman PA, Wood CM, Vassilev AO, Mao C, Uckun FM. Defective expression of Bruton's tyrosine kinase in acute lymphoblastic leukemia. Leuk Lymphoma. 2003;44(6):1011-8.

51. Feldhahn N, Klein F, Mooster JL, Hadweh P, Sprangers M, Wartenberg M, Bekhite MM, Hofmann WK, Herzog S, Jumaa H, et al. Mimicry of a constitutively active pre-B cell receptor in acute lymphoblastic leukemia cells. J Exp Med. 2005;201(11):1837-52.

52. Zhang J, Ding L, Holmfeldt L, Wu G, Heatley SL, Payne-Turner D, Easton J, Chen X, Wang J, Rusch $M$, et al. The genetic basis of early T-cell precursor acute lymphoblastic leukaemia. Nature. 2012;481(7380):157-63.
53. van der Watt PJ, Maske CP, Hendricks DT, Parker MI, Denny L, Govender D, Birrer MJ, Leaner VD. The Karyopherin proteins, Crm1 and Karyopherin beta1, are overexpressed in cervical cancer and are critical for cancer cell survival and proliferation. Int J Cancer. 2009;124(8):1829-40.

54. Shen A, Wang Y, Zhao Y, Zou L, Sun L, Cheng C. Expression of CRM1 in human gliomas and its significance in p27 expression and clinical prognosis. Neurosurgery. 2009;65(1):153-9. discussion 159-160

55. Lapalombella R, Sun Q, Williams K, Tangeman L, Jha S, Zhong Y, Goettl V, Mahoney E, Berglund C, Gupta S, et al. Selective inhibitors of nuclear export show that CRM1/XPO1 is a target in chronic lymphocytic leukemia. Blood. 2012;120(23):4621-34.

56. Neggers JE, Vercruysse T, Jacquemyn M, Vanstreels E, Baloglu E, Shacham S, Crochiere M, Landesman Y, Daelemans D. Identifying drug-target selectivity of small-molecule CRM1/XPO1 inhibitors by CRISPR/Cas9 genome editing. Chem Biol. 2015;22(1):107-16.

57. Vercruysse T, De Bie J, Neggers JE, Jacquemyn M, Vanstreels E, Schmid-Burgk JL, Hornung V, Baloglu E, Landesman Y, Senapedis W, et al. The second-generation Exportin-1 inhibitor KPT-8602 demonstrates potent activity against acute lymphoblastic leukemia. Clin Cancer Res. 2017;23(10):2528-41.

58. Lombard C, Nagarkatti M, Nagarkatti PS. Targeting cannabinoid receptors to treat leukemia: role of cross-talk between extrinsic and intrinsic pathways in Delta9-tetrahydrocannabinol (THC)-induced apoptosis of Jurkat cells. Leuk Res. 2005;29(8):915-22

59. Takahashi K, Inukai T, Imamura T, Yano M, Tomoyasu C, Lucas DM, Nemoto A, Sato $\mathrm{H}$, Huang $\mathrm{M}$, Abe $\mathrm{M}$, et al. Anti-leukemic activity of bortezomib and carfilzomib on B-cell precursor ALL cell lines. PLoS One. 2017;12(12):e0188680.

60. Kochenderfer JN, Dudley ME, Carpenter RO, Kassim SH, Rose JJ, Telford WG, Hakim FT, Halverson DC, Fowler DH, Hardy NM, et al. Donorderived CD19-targeted T cells cause regression of malignancy persisting after allogeneic hematopoietic stem cell transplantation. Blood. 2013; 122(25):4129-39.

61. Maude SL, Frey N, Shaw PA, Aplenc R, Barrett DM, Bunin NJ, Chew A, Gonzalez VE, Zheng Z, Lacey SF, et al. Chimeric antigen receptor T cells for sustained remissions in leukemia. N Engl J Med. 2014;371(16):1507-17.

62. Lee DW, Kochenderfer JN, Stetler-Stevenson M, Cui YK, Delbrook C, Feldman SA, Fry TJ, Orentas R, Sabatino M, Shah NN, et al. T cells expressing CD19 chimeric antigen receptors for acute lymphoblastic leukaemia in children and young adults: a phase 1 dose-escalation trial. Lancet. 2015;385(9967): $517-28$.

63. Eyquem J, Mansilla-Soto J, Giavridis T, van der Stegen SJ, Hamieh M, Cunanan KM, Odak A, Gonen M, Sadelain M. Targeting a CAR to the TRAC locus with CRISPR/Cas9 enhances tumour rejection. Nature. 2017;543(7643):113-7.

64. Topp MS, Gokbuget N, Zugmaier G, Klappers P, Stelljes M, Neumann S, Viardot A, Marks R, Diedrich H, Faul C, et al. Phase II trial of the anti-CD19 bispecific $T$ cell-engager blinatumomab shows hematologic and molecular remissions in patients with relapsed or refractory B-precursor acute lymphoblastic leukemia. J Clin Oncol. 2014;32(36):4134-40.

65. Sotillo E, Barrett DM, Black KL, Bagashev A, Oldridge D, Wu G, Sussman R, Lanauze C, Ruella M, Gazzara MR, et al. Convergence of acquired mutations and alternative splicing of CD19 enables resistance to CART-19 immunotherapy. Cancer Discov. 2015:5(12):1282-95.

66. Locatelli F, Schrappe M, Bernardo ME, Rutella S. How I treat relapsed childhood acute lymphoblastic leukemia. Blood. 2012;120(14):2807-16.

67. Curran E, Stock W. How I treat acute lymphoblastic leukemia in older adolescents and young adults. Blood. 2015;125(24):3702-10.

68. Mukherjee K, Chava AK, Mandal C, Dey SN, Kniep B, Chandra S, Mandal C. O-acetylation of GD3 prevents its apoptotic effect and promotes survival of lymphoblasts in childhood acute lymphoblastic leukaemia. J Cell Biochem. 2008;105(3):724-34.

69. Parameswaran R, Lim M, Arutyunyan A, Abdel-Azim H, Hurtz C, Lau K, Muschen M, Yu RK, von Itzstein M, Heisterkamp N, et al. O-acetylated Nacetylneuraminic acid as a novel target for therapy in human pre-B acute lymphoblastic leukemia. J Exp Med. 2013;210(4):805-19.

70. Baumann AM, Bakkers MJ, Buettner FF, Hartmann M, Grove M, Langereis MA, de Groot RJ, Muhlenhoff M. 9-O-acetylation of sialic acids is catalysed by CASD1 via a covalent acetyl-enzyme intermediate. Nat Commun. 2015;6:7673.

71. LaCasse EC, Mahoney DJ, Cheung HH, Plenchette S, Baird S, Korneluk RG. IAP-targeted therapies for cancer. Oncogene. 2008;27(48):6252-75.

72. Holohan C, Van Schaeybroeck S, Longley DB, Johnston PG. Cancer drug resistance: an evolving paradigm. Nat Rev Cancer. 2013;13(10):714-26. 
73. Suzuki Y, Imai Y, Nakayama H, Takahashi K, Takio K, Takahashi R. A serine protease, HtrA2, is released from the mitochondria and interacts with XIAP, inducing cell death. Mol Cell. 2001;8(3):613-21.

74. Bertrand MJ, Milutinovic S, Dickson KM, Ho WC, Boudreault A, Durkin J, Gillard JW, Jaquith JB, Morris SJ, Barker PA. CIAP1 and CIAP2 facilitate cancer cell survival by functioning as E3 ligases that promote RIP1 ubiquitination. Mol Cell. 2008;30(6):689-700.

75. McComb S, Aguade-Gorgorio J, Harder L, Marovca B, Cario G, Eckert C, Schrappe M, Stanulla M, von Stackelberg A, Bourquin JP, et al. Activation of concurrent apoptosis and necroptosis by SMAC mimetics for the treatment of refractory and relapsed ALL. Sci Transl Med. 2016;8(339):339ra370.

76. Manabe A, Coustan-Smith E, Behm FG, Raimondi SC, Campana D. Bone marrow-derived stromal cells prevent apoptotic cell death in B-lineage acute lymphoblastic leukemia. Blood. 1992;79(9):2370-7.

77. Bruggemann M, Raff T, Kneba M. Has MRD monitoring superseded other prognostic factors in adult ALL? Blood. 2012;120(23):4470-81.

78. Konoplev S, Jorgensen JL, Thomas DA, Lin E, Burger J, Kantarijan HM, Andreeff M, Medeiros L, Konopleva M. Phosphorylated CXCR4 is associated with poor survival in adults with B-acute lymphoblastic leukemia. Cancer. 2011;117(20):4689-95.

79. Juarez J, Bradstock KF, Gottlieb DJ, Bendall LJ. Effects of inhibitors of the chemokine receptor CXCR4 on acute lymphoblastic leukemia cells in vitro. Leukemia. 2003;17(7):1294-300.

80. Juarez J, Dela Pena A, Baraz R, Hewson J, Khoo M, Cisterne A, Fricker S, Fujii N, Bradstock KF, Bendall LJ. CXCR4 antagonists mobilize childhood acute lymphoblastic leukemia cells into the peripheral blood and inhibit engraftment. Leukemia. 2007;21(6):1249-57.

81. Jasin M, Haber JE. The democratization of gene editing: insights from sitespecific cleavage and double-strand break repair. DNA repair. 2016;44:6-16

82. Chiruvella KK, Liang Z, Wilson TE. Repair of double-strand breaks by end joining. Cold Spring Harb Perspect Biol. 2013;5(5):a012757.

83. Jacoby E, Nguyen SM, Fountaine TJ, Welp K, Gryder B, Qin H, Yang Y, Chien $C D$, Seif $A E$, Lei H, et al. CD19 CAR immune pressure induces B-precursor acute lymphoblastic leukaemia lineage switch exposing inherent leukaemic plasticity. Nat Commun. 2016;7:12320.

84. Legut M, Dolton G, Mian AA, Ottmann OG, Sewell AK. CRISPR-mediated TCR replacement generates superior anticancer transgenic T cells. Blood. 2018; 131(3):311-22.

85. Cooper ML, Choi J, Staser K, Ritchey JK, Devenport JM, Eckardt K, Rettig MP, Wang B, Eissenberg LG, Ghobadi A, et al. An "off-the-shelf" fratricideresistant CAR-T for the treatment of $\mathrm{T}$ cell hematologic malignancies. Leukemia. 2018; https://doi.org/10.1038/s41375-018-0065-5.

86. Wang J, Li T, Zhou M, Hu Z, Zhou X, Zhou S, Wang N, Huang L, Zhao L, Cao $Y$, et al. TALENs-mediated gene disruption of FLT3 in leukemia cells: using genome-editing approach for exploring the molecular basis of gene abnormality. Sci Rep. 2015;5:18454.

87. Van Der Meer LT, Yu J, Butler M, Van der Meer JMR, Kuiper RP, van Leeuwen F. Crispr/Cas9 based Kinome screen identifies novel targets that determine sensitivity for Asparaginase therapy in acute lymphoblastic leukemia. Blood. 2015;126(23):2629.

88. Erb MA, Scott TG, Li BE, Xie H, Paulk J, Seo HS, Souza A, Roberts JM, Dastjerdi S, Buckley DL, et al. Transcription control by the ENL YEATS domain in acute leukaemia. Nature. 2017;543(7644):270-4.

89. Nishii R, Moriyama T, Janke L, Yang W, Suiter C, Lin TN, Li L, Kihira K, Toyoda H, Hofmann U, et al. Preclinical evaluation of NUDT15-guided thiopurine therapy and its effects on toxicity and anti-leukemic efficacy. Blood. 2018;131(22):2466-74

90. Huang M, Inukai T, Miyake K, Tanaka Y, Kagami K, Abe M, Goto H, Minegishi $M$, Iwamoto S, Sugihara E, et al. Clofarabine exerts antileukemic activity against cytarabine-resistant B-cell precursor acute lymphoblastic leukemia with low deoxycytidine kinase expression. Cancer Med. 2018;7(4):1297-316.

91. Burns MA, Liao ZW, Yamagata N, Pouliot GP, Stevenson KE, Neuberg DS, Thorner AR, Ducar M, Silverman EA, Hunger SP, et al. Hedgehog pathway mutations drive oncogenic transformation in high-risk T-cell acute lymphoblastic leukemia. Leukemia. 2018; https://doi.org/10.1038/s41375018-0097-x.

\section{Ready to submit your research? Choose BMC and benefit from:}

- fast, convenient online submission

- thorough peer review by experienced researchers in your field

- rapid publication on acceptance

- support for research data, including large and complex data types

- gold Open Access which fosters wider collaboration and increased citations

- maximum visibility for your research: over $100 \mathrm{M}$ website views per year

At BMC, research is always in progress.

Learn more biomedcentral.com/submissions 